\title{
Recovery Dynamics of Perennial Species Following Tropical Cyclone Damage: Introduction to the Workshop
}

\author{
Thomas E. Marler \\ College of Agriculture and Life Sciences, University of Guam, UOG Station, Mangilao, Guam 96923 \\ Bruce W. Wood \\ U.S. Department of Agriculture-Agricultural Research Service, Southeastern Fruit and Tree Nut Research \\ Laboratory, Byron, GA 31008
}

\section{TROPICAL CYCLONES IN THE CONTINENTAL UNITED STATES}

Tropical cyclone (TC) damage to flora is a devastating reality for many regions of the United States. The identification of TC patterns to landfall locations and subsequent paths is important for determining vulnerable regions and planning to avoid or minimize damage. Tropical cyclones are usually initiated within $\approx 8^{\circ}$ of latitude from the equator because of their dependence on the Coriolis force (the force associated with the Earth's rotation that deflects air at a right angle to the direction of rotation) to initiate a vortex circulation (Trewartha, 1968). They are excluded from high latitudes because of the variable position of the subtropical jet stream. Most TCs occur in the Western Pacific Ocean near the Philippines and the South and East China Seas, where they are called typhoons or cyclones. These severe weather

Received for publication 26 May 2000. Accepted for publication 20 June 2000. The cost of publishing this paper was defrayed in part by the payment of page charges. Under postal regulations, this paper therefore must be hereby marked advertisement solely to indicate this fact.

1E-mail address: tmarler@uog9.uog.edu systems are termed hurricanes in the Atlantic and in the Pacific Ocean east of the international dateline. The western North Atlantic, including the Caribbean Sea and the Gulf of Mexico, is the second most likely region to display such storms. These regions encompass some of the primary production zones of many U.S. horticultural crops.

The frequency and paths of Atlantic hurricanes are extremely variable (Diaz and Pulwarty, 1997). For example, from 1900 to 1920 most hurricanes that reached land were in the Gulf of Mexico and the Caribbean Sea. From 1920 to 1940, most were along the Atlantic coast, with very few in the Gulf of Mexico. In the three decades following 1950 the frequency of hurricanes hitting the United States was low, with 1970 having the fewest since 1900 . The 1991-94 period produced relatively few weak Atlantic hurricanes, but the 1995 and 1996 seasons produced about twice as many as normal. This flurry of activity in 1995 and 1996 is thought to have been caused by a prolonged warm El Niño Southern Oscillation (ENSO) phenomenon over the central and eastern Pacific Ocean (Kimberlain and Elsner, 1998). Variation in Atlantic and Caribbean hurricane activity is linked to the mode-like variations of regional and global sea surface temperatures (SSTs) and related trends in global air temperature and pressure anomalies (Gray, 1984). Thus, ENSO characteristics of the Pacific Ocean greatly influence the 
likelihood of hurricane damage to horticultural crops in the continental United States.

The frequency and severity of hurricanes vary substantially within eastern North America (Dunn, 1964). New England is outside the main hurricane belt. Since 1620, only eight hurricanes of Category-3+ (on the Saffir-Simpson Scale) have hit New England. The mid-Atlantic states are also outside the hurricane belt, with no Category-3+ hurricanes making landfall there in recorded history (Dunn, 1964).

The south-Atlantic states are on the northern edge of the hurricane belt, with most hurricanes occurring in August-September (43\%). These hurricanes move in from the Atlantic Ocean, often after skirting Florida. Severe hurricanes hit in this region in 1804, 1813, 1879, 1885, 1898, 1954, and 1958 (Barnes, 1998; Dunn, 1964). Because of the shape of the coastline in this region, most Atlantic hurricanes only skirt the area. Those that do make landfall usually do so along the Coastal Plain of South Carolina and North Carolina, with most of the damage being along the barrier islands. Southeastern Georgia is protected from direct hits from storms because of the northwestward pointing coastline of Florida and the tendency for storms to recurve eastward. Storms coming from the Atlantic Ocean therefore typically bypass southeastern Georgia. This makes the southern half of the Georgia coast line the area least likely to receive a direct hit by a hurricane anywhere along the eastern seaboard of the United States and Mexico from New Jersey to the Yucatan peninsula (Brinkmann, 1975).

The Florida region is the "bull's-eye" of hurricanes, with $\approx 28 \%$ first making landfall in southern Florida. Most occur in AugustOctober (Dunn, 1964). Typically, those in August-September come from the Atlantic Ocean to the east, whereas those in SeptemberOctober come from the Caribbean Sea to the south. Northeastern Florida is protected from direct hits by hurricanes because of the northwestward curvature of the peninsula. In fact, the region around Jacksonville is the only coastal region south of Boston that has no record of direct landfall of a hurricane (Dunn, 1964). The area is, however, subject to damage from weakened storms tracking either up or across the peninsula.

The middle Gulf Coast is also a high-risk area, with most storms moving toward the mouth of the Mississippi River from the Caribbean Sea, after tracking across the Yucatan Channel. About 50\% of hurricanes hitting this area do so in August-September (Dunn, 1964).

The Texas region of the hurricane belt is especially prone to landfall of hurricanes, with $\mathrm{a} \approx 40 \%$ chance of being hit in any given year (Brinkmann, 1975). While hurricanes can strike anywhere along the Texas coastline, $\approx 50 \%$ have struck the southern coast, $\approx 42 \%$ along the central coast, and only $\approx 8 \%$ along the northern coast in recorded history (Brinkmann, 1975).

\section{FUTURE TRENDS}

Economic and biological recovery of horticultural crops from TCs is influenced by the intensity and frequency of recurrent TCs. Thus, environmental changes that influence TC intensity and frequency are important to horticulturists.

The future impact of TCs on the horticulture industry is linked to temperature changes. The source of energy for the maintenance of TCs is latent heat of condensation (Trewartha, 1968). When solar energy strikes the earth's surface, much of it is used in the evaporation of water from plants and land-water surfaces. Solar energy is thus accumulated in the atmosphere as latent, or potential, energy in the form of water vapor. When water vapor condenses, this latent energy is transferred to air where it is retained as the condensed water falls to the ground as precipitation. Air is heated in the process, becomes unstable, or turbulent, and can potentially develop into a storm. Tropical cyclone formation occurs only when ocean surface temperature is above $\approx 26.5$ ${ }^{\circ} \mathrm{C}$. Thus, warmer SSTs within the TC zone lead to more and stronger storms (Knutson et al., 1998).

Global warming over a time-frame of millennia remains to be confirmed; however, warming has occurred in the recent past. Global temperatures in 1998 were the warmest since at least 1860 and probably since at least 1000 A.D., and seven of the 10 warmest years on record occurred after 1990 (Monastersky, 1999). The warming of the earth's surface by $\approx 0.7^{\circ} \mathrm{C}$ since the end of the 19 th century suggests that the Earth is indeed warming, presumably because of accumulation of greenhouse gases in the atmosphere (Monastersky, 1999). Current calculations indicate that the temperature will rise $0.1-0.3{ }^{\circ} \mathrm{C}$ per decade (Mitchell and Jones, 1997; Wigley et al., 1996). If this average warming in turn warms ocean surfaces, which is probable, then hurricane intensity and severity will increase.

Certain "general circulation models" indicate that a doubling of the present levels of atmospheric greenhouse gases will increase the destructiveness of hurricanes by $40 \%$ to $50 \%$ (Goudie, 1996). Atmospheric $\mathrm{CO}_{2}$ has risen $\approx 25 \%$ since pre-industrial times (Moghissi, 1996), and has increased $\approx 1.5 \mathrm{~mL} \cdot \mathrm{L}^{-1}$ per year in recent decades (Peixoto and Oort, 1994). Thus, a continuation of this trend would probably result in increased TC damage to the U.S. horticulture industry. However, if alteration of the climate by greenhouse gases is accompanied by volcanic eruptions of sufficient frequency and intensity, the result could be global cooling. Such eruptions have had major long-lasting cooling effects on global SSTs in the past and appear to reduce hurricane frequency and intensity (Kerr, 1989; Rampino and Self, 1992)

\section{IMPACT ON HORTICULTURE}

Tropical cyclone damage to plants and the dynamics of recovery following damage have received considerable attention for natural plant systems. Entire issues (e.g., Biotropica 23, No. 4a) or sections within issues of journals (e.g., Biotropica 28, No. 4a) have been devoted to the subject. Moreover, direct TC damage has been described for certain perennial horticultural crops (e.g., Campbell et al., 1993). However, despite acknowledgment that the influence on crop production by the passage of a TC lasts for many years, post-TC recovery dynamics of horticultural crops has received little attention.

Damage during a TC is a function of species, population, site, and meteorological characteristics. The acute, short-term stresses associated with the passage of a TC interact with other physical, chemical, and biotic stresses to create a multidimensional recovery process. Certain aspects of resistance to and recovery from TC damage are directly influenced by horticultural management decisions.

Most horticulturists in the production zones of the United States where TCs are possible rarely take into account the meteorological reality of the yearly threat of direct TC damage. This oversight may result from the relative infrequency of TCs and the fact that individual managers of long-lived perennial crops may not experience a TC during their tenure. It may also stem from a sense that TCs are so destructive that horticultural management decisions will not affect the extent of damage should a TC occur. However, the paucity of direct studies by the horticultural research community may be the most logical explanation for the casual or nonexistent inclusion of TCs into horticultural management plans.

This workshop was organized by geographical region because of the influence of agro-ecological factors on the impact and recovery of crops from these weather systems. The information in these proceedings has direct application to managing orchard recovery following TC damage. However, because of the similarities among many largescale disturbances, the information may also have application to managing recovery from other natural disturbances, such as fire and severe freeze damage, and extreme horticultural operations, such as severe summer pruning. Furthermore, the information may aid in landuse planning, improved assessment of yield losses, decisions to rogue or reset trees, and many other crop management decisions associated with horticulture in regions affected by TCs.

\section{Literature Cited}

Barnes, J. 1998. North Carolina hurricane history. Univ. of North Carolina Press, Chapel Hill.

Brinkmann, W.A.R. 1975. Hurricane hazard in the United States: A research assessment. Inst. Behavioral Sci., Univ. of Colorado Press, Boulder.

Campbell, R.J., C.W. Campbell, J. Crane, C. Balerdi, and S. Goldweber. 1993. Hurricane Andrew damages tropical fruit crops in South Florida. Fruit Var. J. 47:218-225.

Diaz, H.F. and R.S. Pulwarty. 1997. Decadal climatic variability, Atlantic hurricanes, and societal impacts: An overview, p. 1-27. In: H.E. Diaz and 
R.S. Pulwarty (eds.). Hurricanes: Climate and socioeconomic impacts. Springer, New York.

Dunn, G.E. 1964. Atlantic hurricanes. Louisiana State Univ. Press, Baton Rouge

Goudie, A.S. 1996. Geomorphological hotspots and global warming. Interdisciplinary Sci. Rev. 21:253-259.

Gray, W.M. 1984. Atlantic seasonal hurricane frequency. Part I: El Niño and 30-mb quasi-biennial oscillation influences. Monthly Weather Rev. 112:1649-1668.

Kerr, R.A. 1989. Volcanoes can muddle the greenhouse. Science 245:127-128.

Kimberlain, T.B. and J.B. Elsner. 1998. The 1995 and 1996 North Atlantic hurricane seasons: A return of the tropical-only hurricane. J. Climate 11:2062-2068.

Knutson, T.R., R.E. Tuleya, and Y. Kurihara. 1998. Simulated increase of hurricane intensities in a carbon dioxide warmed climate. Science 279:10181020 .
Mitchell, J.F.B. and T.C. Jones. 1997. On the modification of global warming by sulphate aerosols. J. Climate 10:245-267.

Moghissi, A.A. 1996. Global warming-Facts and their implications. Environ. Intl. 22:657-660.

Monastersky, R. 1999. Earth's temperature shot skyward in 1998. Sci. News 155:6.

Peixoto, J.P. and A.H. Oort. 1994. Interannual and interdecadal variability in the climate system, p. 412-475. In: J.P. Peixoto and A.H. Oort (eds.). Physics of climate. Amer. Inst. Physics, New York.

Rampino, M.R. and S. Self. 1992. Volcanic winter and accelerated glaciation following the Toba super-eruption. Nature 359:50-52.

Trewartha, G.T. 1968. An introduction to climate. McGraw-Hill, New York.

Wigley, T.M.L., R. Richels, and J.A. Edmonds. 1996. Economic and environmental choices in the stabilization of atmospheric $\mathrm{CO}_{2}$ concentrations Nature 379:240-243. 